International Journal of Instruction e-ISSN: 1308-1470 • www.e-iji.net

Article submission code: 20191216195503

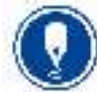

January $2021 \bullet$ Vol.14, No.1

p-ISSN: 1694-609X

pp. $427-444$

Received: $16 / 12 / 2019$

Revision: 30/06/2020
Accepted: $21 / 07 / 2020$

OnlineFirst:25/10/2020

\title{
Dominant Language Competences in the Contemporary Teaching of History as a Prerequisite for a Successful Teaching Process
}

\author{
Vjera Brković \\ Lecturer, Catholic University of Croatia, Croatia, vjera.brkovic@unicath.hr
}

Rona Bušljeta Kardum

Asst. Prof., Faculty of Croatian Studies, University of Zagreb, Croatia, rona.busljeta@gmail.com

\section{Marijana Togonal}

Asst. Prof., Catholic University of Croatia, Croatia, marijana.togonal@unicath.hr

$$
\mid
$$

Contemporary theories and approaches to teaching greatly emphasize the importance of students in the teaching and learning process. While it is unquestionable that students should be at the heart of the teaching and learning process, this paper seeks to emphasize the importance of the overall quality of teacher proficiency with an emphasis on language proficiency. In order for communication between students and teachers to flow smoothly, it is extremely important for teachers to be linguistically educated and linguistically competent to handle their work. Teachers in Croatian schools obtain the final certification of their qualifications by passing a professional qualification examination, which, among other things, examines their ability to communicate in a standard language. The aim of this paper is to determine the extent to which teachers have mastered the standard language norm on the basis of a linguistic analysis of the content of the essays written by the candidates in the professional qualification examination. For the purpose of our work, we have chosen history teachers, since in our daily work with history students we have noticed numerous difficulties in their written expression, from spelling through grammar to lexical and stylistic imperfections. Based on the obtained results, we found that history teachers did not sufficiently master the norms of standard language during their studies, and that they made numerous linguistic errors in their essay entries, in all normative levels, which indicates a mandatory need to implement language courses in all history studies.

Keywords: Croatia, history studies, professional qualification examinations, professional essays, teacher language competences

Citation: Brković, V., Kardum, R. B., \& Togonal, M. (2021). Language Competences in the Contemporary Teaching of History as a Prerequisite for a Successful Teaching Process. International Journal of Instruction, 14(1), 427-444. https://doi.org/10.29333/iji.2021.14125a 


\section{INTRODUCTION}

The issue of language and language policy is sensitive in all countries that have been part of a larger community for centuries. Stronger and more powerful nations have determined not only general politics, social and economic order, geographical integrity, cultural progress, educational policy, but also language development, and especially its social status (Spolsky, 2004; Barić, 2015). Croatia is one of the oldest European countries in terms of its history and culture. Croatia's rich history contains important moments of struggle for state-political as well as Croatian linguistic independence from the $12^{\text {th }}$ to the $20^{\text {th }}$ century through alliances within different state entities. (Krstić, 2015). In multi-ethnic communities, the Croatian language developed in the rich literary production of Croatian writers and gradually underwent a process of standardization. However, only in 1991 did it succeed in acquiring the status of an independent and official language of public communication (Badurina, 2001). Although many small countries, which have a similar history to Croatia, have adopted a language law that seeks to protect the standard language in public use, Croatia has no such law. For example, a language law was adopted by France, Italy, the Czech Republic, Hungary, Slovakia, Slovenia, Macedonia, Serbia and other countries, defining the use of language in public and official communication. In 2010, the Croatian Labour Party sent an amendment to the Croatian Parliament to pass such a law in Croatia, however, it was rejected. Although a large number of Croatian linguists have supported the proposal, which has been updated several times since 2010, the general public views it as a parody of linguistic police punishing bad speakers. It is obvious that Croatian linguists have not sufficiently expressed, nor clearly and reasonably explained to the public why such a law would be necessary and what areas of language use would be regulated.

Considering the importance of standard language as a part of national identity, we believe that its preservation and nurturing should be systematically cultivated, mostly within the educational process and educational policy (Škiljan, 1988; Spolsky, 2016). Language competences represent one of the key competences that every individual should possess, regardless of their level and type of education (Key competences in adult learning). Language competences are especially important for the teaching profession, as language is the key tool with which teachers transmit their knowledge and skills to students. In order for teachers to master the linguistic norm sovereignly and independently, systematic language education is required. This can be achieved through listening and taking a collection of language courses, which should be mandatory during their studies. In view of the constant changes taking place in languages, it would be advisable for teachers to enhance and improve their language skills by attending various workshops, seminars and other forms of education, as a part of lifelong learning programs. The importance of mastering the standard norm, for example, is shown by the fact that the professional qualification examinations, which every teacher in the Croatian education system must take, evaluate the teacher's ability to communicate in a standard language as a prerequisite for passing the examination. In addition to Croatian language teachers, history teachers are teaching students specific historical circumstances that influenced certain developmental phases of the Croatian language, revealing and analysing a context that, among other things, directly influenced the social status of the 
language. Due to this, we consider it extremely important that not only must they have a theoretical knowledge of the language and its history, but in their daily work with students, they also apply the standard norm as a type of linguistic prestige appropriate for schools and education. In order to determine the extent to which history teachers have mastered the standard norm, we analysed the essays they wrote within the professional examination, covering a period of four years, from 2016 to 2019. The analysis included applicants from nine Croatian counties, or about $60 \%$ of the total number of applicants who passed the professional examination during the previously mentioned period. We aimed to determine, on the basis of linguistic analysis of the written work, the extent to which history teachers mastered the linguistic norm, which language problems were most commonly found, and whether or not they had acquired sufficient linguistic competences during their studies to communicate freely in standard language. The aim was also to identify, on the basis of the obtained results, the potential weaknesses of the history study programs and to propose changes to them in order to synchronize them with the fundamental documents of the European Union relating to key competences for lifelong learning, among which communication in the mother tongue was put in first place. The motive for research on the level of written competence of historian apprentices (future history teachers) is based on experience. Specifically, in working with students, it has been observed that a large number of students have difficulties in expressing themselves in writing and that, in doing so, they make numerous linguistic errors that often affect the understanding of the content of the text. It is precisely on the basis of experience that the initial hypothesis of this work on the lack of language education of history teachers was formulated.

Since no research has been done so far in Croatia on the language competences of history teachers, linguistic analysis of the content of essays gave an objective picture of the general literacy of future history teachers. Although it is not explicitly established in Croatia which domains (e.g. religious, educational, political, judicial, etc.) are part of the field of public communication (Kovačević \& Badurina, 2001), it is undoubted that teachers - stakeholders of the educational process - hold public office and that given their public role, they should be able to use the sovereign standard language as an idiom of public communication. The obtained results show that, to a large extent, teachers do not follow the standard norms, which directly indicates deficiencies in the concept of history studies in Croatia.

\section{LITERATURE REVIEW}

\section{Teachers' competences}

Recent scientific and professional literature related to the teaching of history, stating the goals of teaching history (Counsell, K., Burn, K., Chapman, A., 2016, Symcox, L., Wilschut, A., 2009., Harris, R., Burn, K., Woolley, M., 2004) points out that a high quality teaching process requires a well-designed, structured and guided teaching process from the teacher. In this regard, it is important for a history teacher to excel in communication and presentation skills, but also to have all other necessary professional knowledge and competences (Archer \& Hughes, 2011; Cohan \& Honigsfeld, 2011; 
Halimah \& Sukmayadi, 2019), among which linguistic competence should definitely be emphasized.

The European Commission highlights in its document A new skills agenda for Europe Working together to strengthen human capital, employ ability and competitiveness, the worrisome statistic that a quarter of Europe's adult population has problems with basic competences, such as reading and writing skills, along with mathematical and digital skills. It is unknown whether individuals in the teaching profession fall into this category. However, the document especially highlights the need for excellent teachers who will be able to convey a wide range of skills and knowledge to students which they will apply later on in life and future work.

In this part of the paper, we would like to determine the competences of teachers required by the new model of the teaching and learning process, and for that we will consult some Croatian and European documents relevant for defining the knowledge and skills necessary for teachers. The European Council document, translated into Croatian as The Council Recommendation on Key Competences for Lifelong Learning, clearly outlines the eight key competences that each individual needs for personal growth and development, active civic life, social integration and employment, i.e. the competences needed for living and working in the 21st century. Among these competences, literacy competence is listed in first place, followed by multilingual competence, competence in numerical, scientific and engineering skills, digital and technology-based competences, interpersonal skills and the ability to adopt new competences, competence for active citizenship, entrepreneurial competence and competence for cultural awareness and expression. Literacy competency, which, as mentioned above, is the first competence listed, implies the acquisition of communication skills in the mother tongue, i.e. the development of the ability to gather and process information and to express one's own argumentative views in both spoken and written form. Specifically, the document states that literacy competence includes "the knowledge of reading and writing and a sound understanding of written information and thus requires an individual to have knowledge of vocabulary, functional grammar and the functions of language." In addition to these recommendations, Tuning Educational Structures in Europe: Summary of Outcomes Education highlights the generic and specific competences that teachers should possess. Specific competences, among other things, state that teachers should have knowledge of the subjects they teach, understand the structure and purpose of education systems, be aware of the different roles of participants in the learning process, be able to respond to the different needs of students, encourage a positive classroom climate, develop learning strategies. to encourage achievement and to monitor student progress, to continuously hone their craft through professional development, analyse and self-evaluate their own work. The same document also lists generic competences, in addition to basic knowledge related to the field of work, critical and self-critical skills, the ability to cope in new situations, research skills, etc., oral and written communication in the mother tongue is particularly emphasized as a generic competence. In addition to the aforementioned documents for defining key competences, the OECD project The Definition and Selection of Key Competences in which the first competence listed is the interactive use of language tools, symbols, texts, information and technologies, is also 
important. In addition to the above documents, there are other European documents that set out the required competences of teachers, such as Supporting teacher competence development for better learning outcomes (2013), Common European Principles for Teacher Competences and Qualifications (2005), Teacher Education in Europe: An ETUCE Policy Paper (2008), however, for the purposes of this paper, we have chosen those documents which clearly emphasize the need for developing language competences in future teachers.

Since we have committed ourselves to accept the guidelines of Europe's educational policy, and so a large number of European documents become relevant when it comes to education in Croatia, we will also analyse what defines education policy in Croatia when it comes to education and the acquisition of teacher competences. Thus, The Framework of the National Standard for Qualifications for Teachers in Primary and Secondary Schools, adopted by the National Council of Education in 2016 as an umbrella document for the development of the teaching profession in Croatia, professional communication and interaction are mentioned as one of the qualifications. This qualification, defined as a set of outcomes, states that teachers should "express themselves accurately and fluently in spoken and written communication in the language of instruction and the official language" and propose an "analysis of the application of the spelling, grammatical and syntactic rules of the official language and the language of instruction in course preparation and based on observation of the candidate's expression in spoken and written communication, during examinations." From the analysed documents, it is clear that language competences, both written and spoken, knowledge of the standard language rules as the language of official, public communication and their functional application are part of the so-called generic competences of teachers which they should sovereignly master and on which the success of the teaching process often depends.

Even though the importance of communicative competence or competence for language use as opposed to linguistic competence (knowledge of the norm) is increasingly emphasized in professional and scientific literature dealing with linguistic competences (Cooley \& Roach, 1984, Jelaska, 2005, Bagarić \& Mihaljević Djigunović, 2007), we believe that the teacher, whether we view them from a traditional (centre of the teaching process) or a contemporary (organizer and moderator of the teaching process) aspect, they must be equally well equipped to master both competences: in both, the theoretical and applied sense.

\section{Language competences}

At the beginning of the 20th century, F. de Saussure divided linguistic functions (langage) into language (langue) and speech (parole) as part of his linguistic work, defining langue as an abstract system of characters, and parole as its verbal realization, and in doing so, he actually paved the way for the subsequent division of linguistic ability into linguistic and communicative. Language is a social product, a social given, a code whose character system, agreed within a particular linguistic community, we must know in order to participate in the communication process. Speech, however, is a verbal realization of this code, an individual act based on knowledge of the linguistic code, it is 
individual and unique, and it reflects the speaker's knowledge of the language, but also all non-linguistic reality: age, gender, experience, social status, educational status, social environment, paralinguistic characteristics, cognitive ability, etc. Language, therefore, consists of a conventional set of rules that, as we grow up, we adopt consciously (institutional language learning) and unconsciously (through the method of perception and imitation, model learning), which are manifested in speech. Langue and parole are interdependent language categories that are realized in language production in different language activities: those related to receiving (listening, speaking) and those related to production (reading, writing). The acceptance and application of all four branches of language functions within the framework of teaching is based on the linguistic knowledge and language skills of the participants in the teaching process: the teachers and the students.

The very concept of linguistic ability and linguistic competence in linguistics has been intensively debated since the 1960s, largely thanks to the works of N. Chomsky. Examining the idealized speaker, Chomsky (1965) introduces the term linguistic competence by referring to the speaker's knowledge of a particular language, its rules, grammar. Therefore, according to Chomsky's interpretation, linguistic competence could also be called grammatical or normative competence. For Chomsky, the idealized speaker is one who knows the grammatical rules of their language, thus, Chomsky equates linguistic knowledge with the knowledge of linguistic rules and norms, along with the knowledge of the system of the individual linguistic code that the speaker uses to communicate. In his work, Chomsky does not analyse the performance part of this systemized and regulated code described in specific communication situations but focuses solely on linguistic knowledge. Chomsky and his followers thus dealt with knowledge in their works, namely knowledge of language, linguistic rules, grammar, i.e. language as an autonomous phenomenon independent of society and its development. The development of psycholinguistics and sociolinguistics changes the attitude towards language. The study of language as a system of symbols and signs governed by rules whose knowledge enables the speaker to produce an unlimited series of sentences, each of which can be grammatically described, is being increasingly abandoned (Chomsky, 1965). Unlike such closed normative approaches to language, psycholinguists and sociolinguists approach language as an open system which is determined psychologically and socially. Language truly does consist of a series of rules that describe and prescribe it, and in this sense, it is a closed system, but at the same time it is open to numerous extrinsic influences that affect its changes. Considering the achievements of linguistics hitherto, new linguistic trends in their reflections on language start from a wider non-linguistic environment, taking into account that it has a profound effect on the language of an individual, and a group (Sternberg, 2004). Within sociolinguistic research on language and linguistic development, the term communicative competence emerges (Haymes, 1972), which, unlike linguistic competence, i.e. knowledge of the language as a normative system, encompasses knowledge of the language in real communication situations, i.e. knowledge (and/or ability) to select language resources from a language system appropriate to a particular situation. Since they take into account socially realistic factors beyond the language, 
which influence the speaker's linguistic code, sociolinguists abandon the term idealized speaker and talk about the actual speaker. The actual speaker will know how to functionally apply linguistic knowledge, taking into account the differences and specificities of particular communication situations. The actual speaker is fluent in the language, and in order to successfully master the language, they must be proficient in both the linguistic rules and the non-linguistic rules.

Since ancient times, it has been known that expertise in linguistic norms is one of the many abilities a successful speaker/communicator must possess. Thus, for example, in writing his Rhetoric on clarity as a major feature of good spoken style, Aristotle cites proper speech in the Hellenic language as a prerequisite for its realization, which cannot be achieved without a good knowledge of linguistic rules. In this context, Aristotle speaks of some universal normative rules: proper use of punctuation (spelling norm), proper use of conjunctions and connectives (syntactic norm), proper use of certain words and expressions (lexical norm, stylistic norm), correct use of gender and number of names (morphological norm) et al. (Aristotle, 1989). Although Aristotle does not elaborate and problematize knowledge of linguistic norms in detail in his Rhetoric, the rules of the Hellenic language persist throughout the book as a conditio sine qua non of refined linguistic culture and chosen spoken style. Namely, Aristotle wonders in Rhetoric, how would it be possible to achieve harmony in speech, clarity of style, use words correctly in certain contexts, and leave a strong impression on the interlocutor at all without obeying linguistic rules? When, for example, in his book On the Orator, Cicero states the knowledge, skills and abilities that a true speaker should possess, among other things, he also speaks of linguistic and communication competence: "[...] the whole art of speaking lies before us, and is concerned with common usage and the custom and language of all men". Cicero continues by saying that to speak properly, one need not only take care of using words that no one can rightfully object to and respect their cases, tenses, numbers and genders and avoid uttering things badly, unharmoniously or in a wrong order. One must manage tongue, breath and even the sound of one's voice. Sounds shouldn't be uttered with too much affectation or be unclear due to casual pronunciation; one shouldn't form words using exhalation that is too weak, but they also shouldn't be too puffed up or exhaled too zealously. One must acquire knowledge of many things without which the dexterity of words is empty and ridiculous. The speech itself must be formed not only by choosing proper words but also by putting fitting words together; all the feelings given by nature to humanity must be thoroughly studied because all the force and meaning of the speech must be uttered to calm or excite the souls of the listeners. In his speaker's manual, in several places Cicero points out that it is necessary to speak in the proper Latin language. In other words, in order to achieve the pathos that Aristotle cites in his Rhetoric as one of the three key factors of speech, the speaker must have knowledge of the language, and therefore be linguistically competent. Even though he doesn't name them, Cicero actually speaks of the norms of standard language: the use of words (lexical norm), adherence to grammatical case, verb tense, person and number (morphological norm), word order (syntactic norm), pronunciation of sounds and words (phonological and prosodic norm), word selection (stylistic norm), etc. (Cicero, 2002). Thus, according to 
Cicero, the speaker's discourse is a reflection of a broad knowledge of the content they are talking about, but only in combination with the knowledge of linguistic principles (linguistic competence) that they apply by shaping the content as a message intended for the listener (communicative competence) will the speaker be able to elicit the desired pathos, i.e. influence the listener's feelings and emotions. Although they did not use terms such as communication and linguistic competence, the old rhetoricians, writing instructions on what skills a public speaker should master, included knowledge of linguistic norms (knowledge of the language as a system) and its proper implementation i.e. situational parameters (knowledge of the language as a standard). In the document Common European Framework of Reference for Languages: Learning, teaching, assessment (2011), linguistic and communication competences are not separated, but rather combined into one: communicative language competence, which in turn has three components: linguistic, sociolinguistic and pragmatic.

Since the educational process falls under the field of public communication and standard language is the medium of public communication, teachers/lecturers are expected to possess above-average linguistic skills: linguistic, sociolinguistic, and pragmatic. Given the public function that teachers carry out and the linguistic influence they have on their audiences (pupils and students), all teaching studies, including history studies, should implement courses that teach the standard idiom in their study programs. According to Trask, the standard language in all nations was created by agreement, as a type of cohesive element between the idiolectic and idiomatic disparate members of a particular linguistic community (Sapunar Knežević \& Togonal, 2012). Trask (2005) continues by saying that standard language is precisely the variation of a language that speakers consider most appropriate for official communication and for education. Although regulations or other legal acts do not stipulate that stakeholders in the educational process must use the standard idiom, they are still expected to be proficient in the standard language and to use it perfectly.

\section{METHOD}

\section{Research Model}

The quantitative method of analysing the content of performance plans and programs in history studies in Croatia and the qualitative method of analysing the content of essays written by applicants in their professional examinations were used as a research method. (Krippendorff, 2004). In Croatian universities and colleges, there are eight history study programs to educate future history teachers. Since linguistic knowledge and skills are key tools in teachers' work, and these tools are not self-explanatory but should be continuously acquired, nurtured, improved and supplemented, it is expected that teacher studies, as well as history studies, include mandatory language courses in their study programs. 
Table 1

Display of language courses in history studies in Croatia

\begin{tabular}{lll}
\hline Name of Institution & Language Course & Mandatory/Elective \\
\hline Josip Juraj Strossmayer University of Osijek & No & $/$ \\
\hline Juraj Dobrila University of Pula & Yes & mandatory \\
\hline University of Rijeka & Yes & mandatory \\
\hline University of Split & No & $/$ \\
\hline University of Zadar & No & $/$ \\
\hline Catholic University of Croatia & Yes & elective \\
\hline $\begin{array}{l}\text { Faculty of Humanities and Social Sciences, } \\
\text { University of Zagreb }\end{array}$ & No & elective \\
\hline Croatian studies & & \\
\hline
\end{tabular}

Investigation of the representation of language courses in history studies in Croatia (see Table 1), however, showed that only two studies have compulsory language courses, three exist as electives, so students may or may not take them, while three faculties have neither compulsory nor elective language courses. Considering such a structure of history studies, it is concluded that previously acquired language skills (at the secondary level) are good enough for sovereign language proficiency as a fundamental tool for teachers to convey knowledge, skills and abilities to students. Such a sentiment is further supported by the fact that a certain (previously agreed upon) level of knowledge of language rules and their functional application are not considered a necessary prerequisite for teaching, as teachers are not subjected to any targeted language evaluations to assess their language proficiency in teaching. Job application documentation does not require prospective teachers to certify their level of proficiency of mother tongue language norms, however certification is required by a job applicant who is expected to be proficient in a foreign language. In that case, the job vacancy notice regularly states the required level of foreign language proficiency (as defined by the 2001 Common European Framework of Reference for Languages document adopted by the European Council). The level of a teacher's written language competence can only partially be determined during their professional qualification examination. According to the Rulebook on the Professional Examination of Teachers and Professional Associates in Primary Schools and Educators in Secondary Schools, adopted by the Croatian Ministry of Education and Sports in 2003, graduates have the right to undertake the professional qualification examination only after having completed internships at a school or after volunteering in a teaching position (Art. 3). Internships begin on the day the trainee's employment is established or the day on which the volunteering contract is initiated. (Art. 7). Thus, at the moment of taking the internship exam, which finally confirms their qualifications for teaching, a teacher has completed history studies, has at least one year of experience in teaching, and their work during the internship must be overseen by a mentor. Intern teachers are obliged to attend the mentor's classes for at least 30 hours during the internship, and the mentor is obliged to attend the intern's classes for 10 hours (Art. 10). The professional qualification examination for teachers includes written work, written preparation for a class, teaching 
the class and an oral examination. (Art. 19). From all four parts of the exam, one can get a picture of the language competences of a teacher, in both written and verbal forms, but in no part of the exam are they directly scrutinized.

Since the most objective insight into the language competences of teachers is obtained through the analysis of written work, the subject of our qualitative analysis will be the essays written by the applicants within the internship examination, with the purpose of confirming or disproving the initial hypothesis regarding the lack of linguistic knowledge among history teachers. The essay is written in 180 minutes, and it assesses the candidate's knowledge of the given topic, their ability to logically and reasonably present the material, and apply the rules of standard language norms. For this reason, apart from history teachers, the essay is also evaluated by a Croatian language teacher. The analysis includes essays written from February 2016 to October 2019. In analysing the content, while determining the degree of literacy of the essays, we started with the normative rules of the Croatian standard language: orthographic, grammatical, syntactic, lexical and stylistic.

\section{Presentation of passing rates of the written part of the examination}

The written portion of the professional qualification examination in history is composed of two parts, one related to the professional-pedagogical level of the topic covered and knowledge of the material and the other dealing with general literacy i.e. on the application of the rules of standard language norms while discussing the topic. In order for candidates to receive a passing grade, both parts of the paper should be rated with a positive grade.

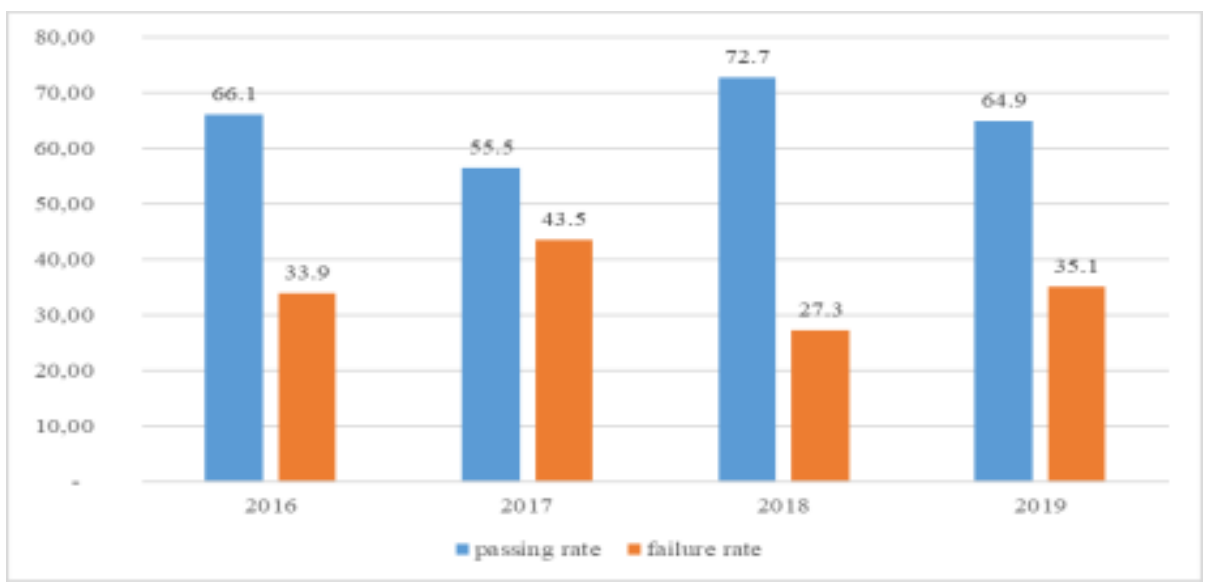

Figure 1

Presentation of the passing and failure rates of candidates taking the professional qualification examination in history

This graphic presentation shows the total passing and failure rates of candidates in the written portion of the examination during the observed period. The left column shows the results of those applicants who passed on both parts of the paper: 66.1\% (2016), 
$56.4 \%$ (2017), $72.7 \%$ (2018) and $64.8 \%$ (2019). The right column shows the results of the applicants who failed the exam, one part or both parts. As can be seen in the graph, more than a third of the applicants do not pass the written portion of the examination: $33.9 \%$ (2016), 43.5\% (2017), 27.7\% (2018) and 35.1\% (2019). In interpreting the results, it is important to emphasize that these are graduate historians, teachers who have either already entered the education system and are already working directly with students or, if they choose to remain in education, will newly enter the system, so we consider this percentage of decline to be a concern.

Furthermore, through analysis and organization of the essays by the year they were written, and guided by the standard language norms, we have found that the applicants are largely unaware of the elementary normative rules of the Croatian standard language and have difficulty expressing themselves in writing within the framework of the assumed functional style - professional and scientific. Linguistic analysis confirmed that the candidates made mistakes at all normative levels. For the purpose of this paper, we have isolated examples of deviations from the standard norm, which were continuously repeated in most of the essays.

1. Orthographic level: uppercase and lowercase letters, writing graphemes with diacritical characters, using commas, quotation marks, compound and noncompound words, incorrect negation with verbs, disregard for consistency principles where spelling permits dual forms, the use of individual abbreviations in professional work, etc. The identified orthographic errors clearly and unquestionably indicate that orthographic rules are not automated and that it is a problem for applicants to write even those examples that are considered to be part of professional historical terminology, such as writing historical entities whose subjects are capitalized in Croatian spelling (e.g. The Austro-Hungarian Monarchy, the Venetian Republic, the Ottoman Empire, etc.) or writing specific historical events where only the first word of a multi-word name is spelled with a capital letter.

2. grammatical level (morphological and syntactic): incorrect use of prepositions, the non-normative position of a clitic in relation to a verb, confusion in the use of the definite form and the indefinite form of an adjective, incorrect use of a conditional verb, especially when writing in the first person singular and the first and second person plural, unfamiliarity with the rules in writing the future I tense, sentence incongruence (in the essays, a frequent inconsistency of a verb with the subject in the countability category is evident), irregular order of words in a sentence, etc.

3. lexical level: the most common mistake made by candidates at the lexical level is the use of anglicisms, and usually for examples where acceptable Croatian versions exist.

4. stylistic level: at the stylistic level, the most obvious problem is the disregard for the rules of the defined functional style, in this case scientific, which is especially evident in the level of words, phrases, and even entire sentences that are more appropriate for conversational communication rather than professional and 
scientific. Furthermore, candidates exhibit considerable problems at the stylistic level in vaguely worded sentences that interfere with the comprehension of the text as a whole, unnecessary repetitions of individual words and phrases, stylistically incomplete sentences, and finally, candidates exhibit difficulties in expressing and shaping thoughts, which produces chaos and incoherent content in the text.

Text structure constitutes a special category of problems which primarily relate to the three-part composition of the text, in which three structural parts can be clearly distinguished: introduction, elaboration and conclusion. An analysis of the evaluators' explanations of passing/failure revealed that the most common and severe deviations from the standard norm occur at the syntactic level, referring to word order in a sentence, leaving out certain parts of a sentence, for example, a direct object, which in turn directly affects the coherence and cohesion of the text, and the content's logicality and meaningfulness. Such results coincide with our experience in monitoring students' written expression during their studies, which was the direct motivation for this research. Specifically, we noticed the same language problems and mistakes, and they primarily relate to problems in sentence preparation and text construction, as well as other language problems, from orthographical and phonological to morphological, lexical and stylistic, which we also noticed in working with students. Such a result directly points to the conclusion that students did not sufficiently improve their language culture during their studies and that they left the faculty linguistically incompetent.

\section{FINDINGS}

A comparative analysis of the candidates' essays and the evaluators' reasoning for passing/failure revealed a very low criterion for passing language. Based on the explanations of the evaluator, a conclusion was reached that there are no predefined, clear and balanced criteria for passing the language part of the essay. Due to the absence of such pre-defined passing criteria, it is concluded that a candidate's passing grade is largely left to the subjective will of the evaluator. As linguistic culture is generally declining due to various factors, such as globalization processes that impose English as the language of global communication, the influence of social networks that inaugurate the so-called "new literacy", the decline of the reading culture, the lack of Croatian language classes in schools (3-4 hours per week), etc., which consequently changes the expectations in the proficiency level of the language norm and decreases the language criteria according to which a paper is graded with a passing grade. An analysis of the reasoning of the essay grade indicated the presence of a large number of negative comments in terms of mastery of the language norm, although ultimately, the candidates received a passing grade. 


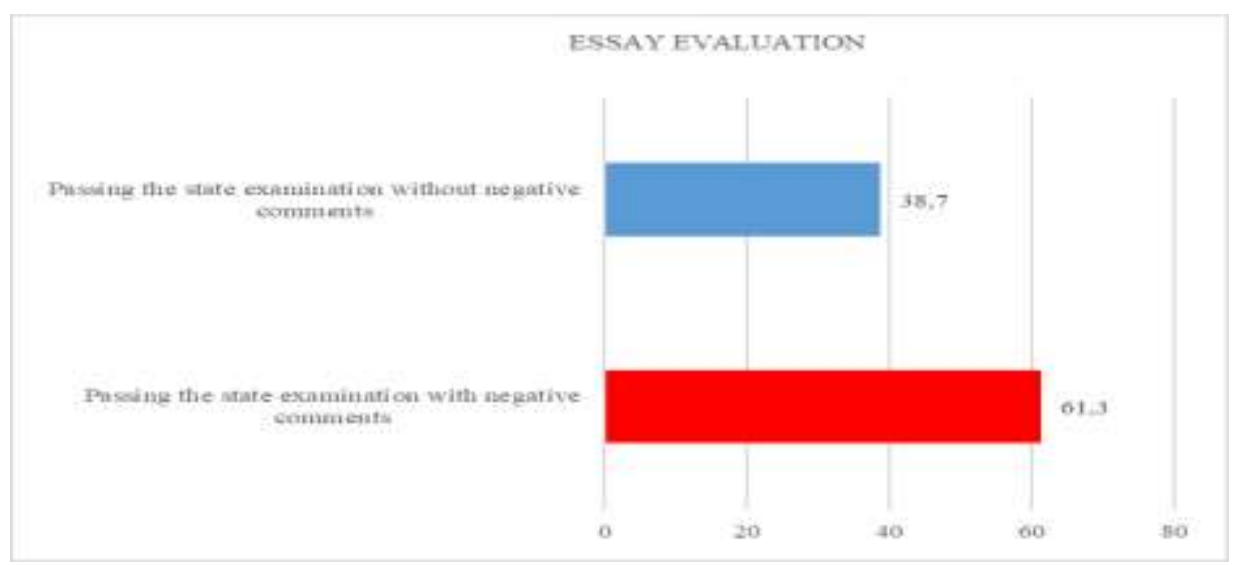

Figure 2

Graphic presentation of passing essays with regard to comments from evaluators

The graph in Figure 2 shows that $61.3 \%$ percent of the essays with regard to language literacy received a passing grade, even though the evaluators noted in their comments that there were continuous violations of the standard norm, at all levels. Some comments are highlighted: mostly knows orthography of the Croatian language, mostly respects the structure of written work, thoughts are mostly clear and logically structured, mainly adheres to a given functional style, clear and accurately formed sentences prevail, deviations from the spelling and grammatical norm are observed, essay contains many lexical-stylistic errors, difficult to understand content due to lexical and semantic imprecision, spelling, grammatical and stylistic errors are observed in the essay, vague and incomplete sentences are observed along with an excessive use of conditionals, nonfunctional repetition of words, work is satisfactory despite linguistic errors, minor deviations from the grammatical norm, the candidate mainly uses technical letters, in a smaller part of the essay the content is written in note form, the written work is saturated with misspellings, minor spelling mistakes are observed, the candidate sometimes violates grammatical norms, more attention is needed in the order of words in a sentence, sometimes the sentences are incongruent, the candidate mainly uses a suitable functional style, the text has deviations from the spelling norm, the content is mostly clear and cohesive, the sentences are generally well formed, in many cases the candidate does not respect the standards of the Croatian standard language, the candidate continuously errs in the writing of future I., the candidate partially respects the spelling norms. As these highlighted comments show, evaluators typically use unmeasurable and unclear magnitudes in their explanations for passing grades: generally, mainly, often, sometimes, mostly, partly, to a lesser extent, to a greater extent.

Since the Rulebook on the Professional Examination of Teachers and Professional Associates in Primary Schools and Educators in Secondary Schools does not specify the criteria for language proficiency, based on analysis of the evaluators' reasoning, we have concluded that the key parameters of language proficiency are the following: 
a) Substantial and graphic three-part structure: introduction, elaboration, and conclusion with indented paragraphs

b) sentences of appropriate length and complexity

c) appropriate functional style

d) clearly and logically arranged thoughts.

Hence, essays that met these criteria received a passing grade regardless of the spelling, grammar, lexical, and other errors observed.

\section{CONCLUSION}

Based on years of work with history students and in monitoring their written expression, it has been observed that many of them have problems with general literacy: from respecting orthographic rules, to particular phonological, morphological, syntactic and stylistic problems. Problems at the syntactic level are particularly pronounced, and above all, they relate to the order of words in a sentence, then the arrangement of entire sentences and their substantial and logical integration into a cohesive and communicative, logically rounded whole. Language skills, both written and spoken, are important for all activities, but they are especially important for teachers. Namely, it often depends on the level of mastery of language skills whether the information will be well received and then well returned, or whether the learning and teaching processes will be successful.

The research presented in this paper was aimed at analysing the written language competences of history teachers in primary and secondary education. The content analysis method was used to analyse the essays that candidates, Bachelor of education graduates, wrote in the state professional examination, as well as the comments of the essay evaluators. By quantitative analysis, we found that in the observed period of four years, $35.6 \%$ of the applicants in nine counties in the Republic of Croatia did not pass the language part of the essay. Qualitative analysis, however, showed that to a large degree, the applicants had not mastered the standards of the Croatian standard language during their education and that they were linguistically incompetent in working directly with students. A comparative analysis of the linguistic level of the content of the essay and the reasoning of the evaluator's grade showed that there is a great deal of discrepancy between the passing rate and the language literacy commentary. Specifically, although $64.4 \%$ of the applicants received a passing grade on the essay, it is still evident from $61.3 \%$ of the evaluators' comments that their literacy level is unsatisfactory given the role they play in the education system. Such results, of course, raise several questions:

a) In what way will linguistically incompetent teachers inspect, analyse and evaluate the written work of their students, such as reports, if they have not mastered the standard norms themselves? 
b) Can students be more linguistically competent than their teachers in some segments, and what consequences does this have on the authority of the teacher as well as the entire teaching profession?

c) In psychology, model-based or learning by imitating a role model stands out as an important form of learning. The simplest acquisition of linguistic principles is precisely based on the imitation of role models. A bad model will be a negative influence on the observer.

The research also showed that there is no pre-defined form according to which the language component of the essay is evaluated, or which could determine a candidate's success or failure in passing the written part of the professional examination. The evaluators correct the text, comment on its linguistic aspect in the form of an explanation of the assessment, but they do not adhere to the same criteria. This can lead to the essay being evaluated negatively with the criteria of one evaluator and yet positively with the criteria of another evaluator.

\section{RECOMMENDATIONS}

Considering the information mentioned in the conclusion, we propose that the existing teacher study programs in Croatia be revised and aligned with the European Commission's lifelong learning documents, which put communication competence first, which is possible by introducing compulsory language courses in all study programs. Furthermore, we propose alterations or amendments to the Rulebook on the Professional Examination of Teachers and Professional Associates in Primary Schools and Educators in Secondary Schools, which must contain clear criteria for passing the professional examination in all its parts, including language. By prescribing criteria (descriptors), candidates will be given clear instructions on what is expected of them in the written part of the exam, and the evaluators will be able to objectively and reasonably substantiate their grade without using vague and unmeasurable descriptive categories, thus reducing the already low language requirements. The predefined criteria allow the evaluator to objectively assess the level of language competence and define the threshold for passing, thus having the function of a kind of analytical matrix with clearly defined guidelines that are applied to each essay. Ultimately, all these activities will have a significant impact on the level of written language culture, which is an extremely important segment of the educational system, both for teachers and students.

\section{REFERENCES}

Archer, A. L. \& Hughes, C. A. (2011) Explicit instruction: Efficient and effective teaching. New York, NY: Guilford Publications.

Aristotel. (1989). Retorika. [Rhetoric] Filozofska biblioteka. ITP Naprijed. Zagreb.

Badurina, L. (2001). Hrvatski jezik kao jezik javne komunikacije. [Public usage of the Croatian standard language] Dometi: znanstveno-kulturna smotra Matice hrvatske. 1-4. 57-62. 
Bagarić, V. \& Mihaljević Djigunović, J. (2007) Defining communicative competence. Metodika. Vol. 8. Br. 1. 94-103.

Barić, B. (2015). Nova država - nova jezična politika. [A New State - a New Language Policy] Kroatologija. 25-44.

Chomsky, N. (1965). Aspects of the Theory of Syntax. Cambridge. MIT Press.

Ciceron, M. T. (2002). O govorniku. [Orator]. Matica hrvatska. Zagreb.

Cohan, A. \& Honigsfeld, A. (2011). Breaking the Mold of Preservice and Inservice Teacher Education: Innovative and Successful Practices for the Twenty-First Century. New York: Rowman \& Littlefield Education.

Cooley, R. E. \& Roach, A. D. (1984). A Conceptual Framework. In Competence in Communication: A Multidisciplinary Approach. Robert N. Bostrom (Ed.). Beverly Hills, CA: Sage.

Counsell, C., Burn, K. \& Chapman, A. (2016). Master Class in History Education. Transforming Teaching and Learning. London: Bloomsbury Academic.

Halimah, L. \& Sukmayadi, V. (2019). The Role of "Jigsaw" Method in Enchancing Indonesian Prospective Teacher's Pedagogical Knowledge and Communication Skill. International Journal of Instruction, 12(2), 289-304.

Harris, R., Burn, K. \& Woolley, M. (2014), The Guided Reader to Teaching and Learning History. London: Routledge.

Hymes, D. H. (1972). On Communicative Competence. In Pride, J. B., \& Holmes, J. (Eds.), Sociolinguistics, 269-293. Baltimore, USA: Penguin Education, Penguin Books Ltd.

Jelaska, Z. (2005) Jezik, komunikacija i sposobnost: nazivi i bliskoznačnice. [Language, Communication and Competences: Terms and Synonyms]. Jezik: časopis za kulturu hrvatskoga književnog jezika. 52(4), 128-138.

Kovačević, M. \& Badurina, L. (2001). Raslojavanje jezične stvarnosti. [Stratification of linguistic reality]. Filozofski fakultet u Rijeci.

Krippendorf, K. (2004). Content analysis: An Introduction to Its Methodology. 2nd ed. SAGE Publications. Thousand Oaks - New Delhi - London.

Sapunar Knežević, A., \& Togonal, M. (2012). Jezična obilježja novinarskopublicističkog stila u hrvatskim tiskanim informativnim medijima. [Linguistic features of journalistic and publicistic style in Croatian print media] Bosanskohercegovački slavistički kongres. Zbornik radova. Knjiga 1, 637-644.

Spolsky, B. (2004). Language Policy. Cambridge University Press. 
Spolsky, B. (2016). Language Policy in Education: History, Theory, Praxis. In McCarty, T. \& May, S. (Eds.) Language Policy and Political Issues in Education. Encyclopedia of Language and Education. 3rd ed. Springer International Publishing.

Sternberg, R. J. (2004). Kognitivna psihologija. [Cognitive Psychology] Naklada Slap. Zagreb.

Symcox, L. \& Wilschut, A. (2009). National History Standards: The Problem of the Canon and the Future of Teaching History. Charlotte, North Carolina: Information Age Publishing

Škiljan, D. (1988). Jezična politika. [Language Policy]. Naprijed. Zagreb.

Trask, R. L. (2005). Temeljni lingvistički pojmovi. [Key concepts in language and linguistitics]. Školska knjiga. Zagreb

\section{Documents:}

A new skills agenda for Europe - Working together to strengthen human capital, employabilityandcompetitiveness. European Commission. 2016. Retrieved 29 September 2019. from https://ec.europa.eu/transparency/regdoc/rep/1/2016/EN/1-2016381-EN-F1-1.PDF

Common European Framework of Reference for Languages: Learning, teaching, assessment. 2001. Council of Europe. Cambridge University Press. Retrieved 29 September 2019 from https://rm.coe.int/16802fc1bf

Common European Principles for Teacher Competences and Qualifications European Commission. 2005. Retrieved 29 September, 2019 from http://www.pef.unilj.si/bologna/dokumenti/eu-common-principles.pdf

Definition and Selection of Competencies: Theorethical and Conceptual Foundations (DeSeCo). OECD. 2001. Retrieved 29 September, 2019 from http://www.oecd.org/education/skills-beyond-school/41529556.pdf

Pravilnik o polaganju stručnog ispita učitelja i stručnih suradnika u osnovnom školstvu i nastavnika i nastavnika u srednjem školstvu. Ministarstvo prosvjete i športa. Zagreb. 2003. Retrieved 1 October, 2019 from https://www.azoo.hr/images/Strucni2012/Pravilnik_st.pdf

Preporuka Vijeća o ključnim kompetencijama za cjeloživotno učenje.Vijeće Europske unije. 2018. Retrieved 1 October, 2019 from https://eurlex.europa.eu/legalcontent/HR/TXT/PDF/?uri=CELEX:32018H0604(01)\&from=EN)

Supporting teacher competence development for better learning outcomes. European $\begin{array}{llll}\text { Commission. } & 2013 . & 1 & \text { October, }\end{array}$ https://ec.europa.eu/assets/eac/education/experts-groups/2011-

2013/teacher/teachercomp_en.pdf 
Teacher Education in Europe: An ETUCE Policy Paper. 2008. 1 October 2019 from https://www.csee-etuce.org/images/attachments/ETUCE_PolicyPaper_en.pdf

Tuning Educational Structures in Europe: Summary of Outcomes-Education. European Commission. 2003. 1 October, 2019 from http://tuningacademy.org/wpcontent/uploads/2014/02/TuningEUI_Final-Report_EN.pdf 